\title{
The Eureka! by Kary Mullis
}

\author{
Lorenzo Gallus, ${ }^{1,2}$ Marco Giammanco, ${ }^{3,4}$ Gian Luigi Mariottini' ${ }^{2,3}$ \\ ${ }^{1}$ Member of the Editorial Board, JBR; ${ }^{2}$ Department of Earth, Environment and Life Sciences, University of Genoa; \\ ${ }^{3}$ Editor-in-Chief, JBR; ${ }^{4}$ Department of Surgical, Oncological and Stomatological Disciplines, University of Palermo, \\ Palermo, Italy
}

Dr. Kary Mullis passed away. In the scientific world, his name was already mythical because his human and scientific history really contained the archetype of genius and recklessness.

We will not remember his fundamental scientific discovery here, we are writing in an experimental biology journal in 2019, it would be useless. We will only remember that his discovery, the Polymerase Chain Reaction (PCR), was the conception of a method; it was therefore the applying of the scientific knowledge already available at the time.

It was a real happy intuition, as he himself recounted in his best-selling autobiography and then in many lectures, interviews and public appearances. All the elements were available in his mind and, at a certain point, the knowledge that he had formed over years of study and work had been arranged in a winning configuration. This insight allowed him to find a solution to a problem he was facing right then. A similar story makes Newton's apple or Archimedes' bath in the tub and his Eureka exclamation plausible.

The importance of his discovery, the consequence that PCR

Correspondence: Lorenzo Gallus, Department of Earth, Environment and Life Sciences, University of Genoa, Italy.

E-mail: galluslorenzo@gmail.com

Received for publication: 11 December 2019.

Accepted for publication: 17 December 2019.

${ }^{\circ}$ Copyright: the Author(s), 2019

Licensee PAGEPress, Italy

Journal of Biological Research 2019; 92:8674

doi:10.4081/jbr.2019.8674

This article is distributed under the terms of the Creative Commons Attribution Noncommercial License (by-nc 4.0) which permits any noncommercial use, distribution, and reproduction in any medium, provided the original author(s) and source are credited. had for science at the end of the $20^{\text {th }}$ century is clearly indicated by these two facts: the PCR method was devised in 1983 and Kary B. Mullis obtained the Nobel Prize in Chemistry in 1993. Ten years from the initial intuition to the Nobel are a clear sign of how much the PCR has been breakthrough.

Two other fundamental steps were the introduction in 1987 of the first prototypes of thermocyclers that automatized the process with the TC1 DNA Thermal Cycler model, a process first performed manually, and the use of the Taq polymerase as early as $1988 .{ }^{1}$

At present, his name, his history and his eccentricity are well known far outside the scientific, medical and legal fields, the three fields that his PCR has completely changed over a few decades.

Criminology enthusiasts, from the avid spectators of documentaries on large crimes, to the fans of successful television series like NCIS and CSI know the PCR and its creator, as Deus ex machina in the world of crime.

Abby Sciuto in the laboratory, the black tresses that fall over the white coat, surrounded by microscopes and pc screens, calls Gibbs excitedly to tell him that the suspect's DNA perfectly coincides with that deposited in the Combined DNA Index System (CODIS). This USA archive, that allows to compare the DNA profiles of crime scenes to those of known criminals, would be unthinkable without PCR.

Similarly, Jurassic Park fans saw in the cartoon in the first film how DNA can be extracted and manipulated to bring the great dinosaurs back to life, it was the early nineties of the last century. The general public, thanks to the book by Michael Crichton and the film by Steven Spielberg, thus approached the concept of molecular paleobiology, made possible precisely by the PCR. ${ }^{2}$

Again, when we look at contemporary medicine, we expect the answers to the questions that doctors and patients ask to science to find solutions, treatments and prevention coming from molecular biology laboratories.

All this would not have been possible without having available large quantities of DNA, and precisely that stretch of DNA that the researcher wants to study, in a relatively simple, automatic, standardized and reliable way.

Mullis was many persons, the boy who produced the rocket propellant he built and launched on his own, the scientist who published an article on Cosmology in Nature in $1968,{ }^{3}$ and an expert in one of the most famous legal trials in the USA. ${ }^{4}$

Mullis uncovered a real treasure chest, and we can now have quantitative PCR, the identification of environmental DNA and, thanks to the impulse given by this technique, we have arrived at the current Crispr-CAS9. Without Mullis and his insights, we would probably be back decades in the field of life sciences.

This is his legacy, the PCR, but also his great trust in science and in scientists, as he has written and said many times, together with a desire for intellectual freedom and sincere curiosity that always animated his life. 
In the coming decades, his figure will surely be read and reread as biographers have already done for the great scientists of the past, yet we will remember what Mullis wrote: for him it was not important to know who really was Isaac Newton, but what mattered was that he showed that force equals mass multiplied by acceleration. The fact that Newton is considered an anti-social fool intent on burning his parents' home certainly does not prevent the force from continuing to equal the mass multiplied by acceleration.

Dr. Kary Mullis will remain the man convinced that there is no questions that cannot be asked.

Finally, we should like to emphasize the great contribution Dr. Kary Mullis gave to our journal, Journal of Biological Research Bollettino della Società Italiana di Biologia Sperimentale (JBR), by accepting to participate as a member in our Editorial Board. His presence undoubtedly increased the prestige of the Journal, allowing to include a very respectful scientist and a Nobel laureate whose reputation is highly recognized by all Science and will remain in the future.
His personal website can be reached here: https://www.karymullis.com/biography.shtml

\section{References}

1. Saiki RK, Gelfand DH, Stoffel S, et al. Primer-Directed Enzymatic Amplification of DNA with a Thermostable DNA Polymerase. Science 1988;239:487-91.

2. Hagelberg E, Sykes B, Hedges R. Ancient bone DNA amplified. Nature 1989;342:485.

3. Mullis KB. Cosmological Significance of Time Reversal. Nature 1968;218:663.

4. Superior Court of the State of California for the County of Los Angeles: The People of California vs Orenthal James Simpson, Case Number BA097211. 